\title{
Comparison between Winkler's extractor and pitfall traps to estimate leaf litter ants richness (Formicidae) at a rainforest site in southest Brazil
}

\author{
Orsolon-Souza, G. ${ }^{a *}$, Esbérard, CEL. ${ }^{b}$, Mayhé-Nunes, AJ. ${ }^{b}$, \\ Vargas, AB. ${ }^{c}$, Veiga-Ferreira, S. $^{a}$, and Folly-Ramos, E. ${ }^{d}$ \\ aPrograma de Pós-graduação em Biologia Animal, Instituto de Biologia, \\ Universidade Federal Rural do Rio de Janeiro - UFRRJ, Rod. BR 465, Km 7, CEP 23890-000, Seropédica, RJ, Brazil \\ ${ }^{b}$ Departamento de Biologia Animal, Instituto de Biologia, Universidade Federal Rural do Rio de Janeiro - UFRRJ \\ 'Programa de Pós-graduação em Ciências Ambientais e Florestais, Instituto de Florestas, \\ Universidade Federal Rural do Rio de Janeiro - UFRRJ \\ ${ }^{d}$ Departamento de Engenharia e Meio Ambiente, Universidade Federal da Paraíba - UFPB, \\ R. Manoel Gonçalves, s/n, CEP 58297-000, Rio Tinto, PB, Brazil \\ *e-mail: guilhermeorsolon@yahoo.com.br
}

Received July 19, 2010 - Accepted November 11, 2010 - Distributed November 30, 2011

(With 2 figures)

\begin{abstract}
The aim of this study was to compare in the same site the efficiency of the two most used techniques for sampling ant diversity, Winkler's extractors and pitfalls. We studied communities of leaf litter ants from the Brazilian Atlantic Forest, compared richness estimates for genera and species, and built species accumulation curves. These two methods resulted in a satisfactory sampling of richness; $21.3 \%$ of the genera and $47.6 \%$ of the species were collected exclusively with Winkler's extractors, whereas $6.4 \%$ of the genera and $9.5 \%$ of the species were collected exclusively with pitfalls. Winkler's extractor had proven to be the most efficient single sampling technique to estimate richness. However, pitfalls also recorded a significant portion of the total richness. Despite differences in efficiency, species accumulation curves for both techniques were similar, as well as the curve obtained with both methods combined. We noticed that Winkler's extractors were c. $74.0 \%$ more efficient than pitfalls in the Atlantic Forest. Therefore, sampling techniques must be used with a well-structured sampling design in order to advance knowledge on the ant fauna of Brazilian biomes, especially in the leaf litter, allowing more complete environmental analyses.
\end{abstract}

Keywords: Atlantic rainforest, sampling techniques, species accumulation curves.

\section{Comparação entre extrator de Winkler e armadilha de queda para estimar a riqueza em espécies de formigas (Formicidae) de serapilheira em floresta tropical do sudeste do Brasil}

\begin{abstract}
Resumo
O objetivo deste estudo foi comparar, em um mesmo ambiente, a eficiência das duas técnicas de coletas mais utilizadas para amostrar a diversidade de formigas, o extrator de Winkler e a armadilha de queda (pitfall traps). Para a comunidade de formigas de serapilheira da Mata Atlântica, comparamos as estimativas de riqueza de gêneros, de espécies e as curvas de acumulação de espécies. Os dois métodos resultaram em uma amostragem de riqueza satisfatória, sendo 21,3 e 47,6\% exclusivamente gêneros e espécies coletadas pelo extrator de Winkler e 6,4 e 9,5\% pela armadilha de queda. O extrator de Winkler mostrou ser a técnica mais eficiente para amostrar a riqueza de uma área quando apenas uma das técnicas possa ser utilizada. No entanto, o uso da armadilha de queda registrou uma parcela não tão desprezível da riqueza. Quanto à eficiência das técnicas de coleta, as curvas de acumulação de espécies para os duas técnicas mostraram-se similares com a obtida com os dois métodos simultaneamente. Notou-se, portanto, que o extrator de Winkler apresenta uma eficiência de amostragem da riqueza na ordem de 74,0\% maior que a armadilha de queda para ambiente de Mata Atlântica. Vale ressaltar que as técnicas de coleta devem estar associadas a um delineamento amostral bem estruturado para que se possa ampliar ainda mais o conhecimento sobre a mirmecofauna dos biomas brasileiros, principalmente daquelas com serapilheira, permitindo análises ambientais mais completas.
\end{abstract}

Palavras-chave: Mata Atlântica, técnicas de coleta, curva de acumulação de espécies. 


\section{Introduction}

Species richness is a central topic in community ecology (Longino et al., 2002) and a fundamental component of biodiversity (Gaston, 1996). However, it is difficult to estimate the species richness of a given area, since the available techniques do not always provide a representative sample of the total richness (Agosti et al., 2000; Agosti and Alonso, 2001).

Studies on communities of leaf litter arthropods (e.g. Romero and Jaffé, 1989; Parr and Chown, 2001) point out the need for well-structured sampling protocols to properly estimate richness and evenness. In the case of ants, foraging area, nest dispersion, and activity patterns are important factors that must be considered in a sampling design (Wang et al., 2001). Researchers of ant communities suggest the combination of different techniques as the best way to estimate richness and abundance of ants (Delabie et al., 2000; Longino et al., 2002).

Pitfall traps, Winkler's extractors, food baits and hand collecting are the most efficient techniques, and, hence, the most frequently used in ant community studies. Both Winkler's extractors and pitfalls have proven to be efficient in sampling abundance and richness of leaf litter ant communities (Romero and Jaffé, 1989; Wang et al., 2001). However, Parr and Chown (2001) compared both techniques and suggested that species sampled with Winkler's extractors are more abundant and smaller than those sampled with pitfalls.

It is also possible to use data obtained with both techniques to estimate species richness. Species accumulation curves allow estimating sample completeness (Colwell and Coddigton, 1994), assessing the efficiency of the method used, and comparing different inventories (Soberón and Llorente, 1993).

Therefore, it is important to compare in the same site the efficiency of the two most used techniques for sampling ant diversity. We studied communities of leaf litter ants from the Brazilian Atlantic Forest, compared richness estimates for genera and species, and built species accumulation curves with data from pitfall traps and Winkler's extractors

\section{Materials and Methods}

\subsection{Study area}

This study was carried out in Dense Ombrophylous Forest (IBAMA, 1996), in the "Reserva Biológica do Tinguá" (ReBio Tinguá, 22 $22^{\circ}$ '-22 $32^{\circ}$ ' S and $43^{\circ} 13^{\prime}$ $43^{\circ} 34^{\prime}$ W), Nova Iguaçu municipality, state of Rio de Janeiro, in November 2003. Sampling was carried out in submontane rainforest (Veloso et al., 1991) at $400 \mathrm{~m}$ asl on average.

\subsubsection{Characterisation of submontane rainforest}

Submontane rainforest presents canopy height varying from 15 to $20 \mathrm{~m}$ on average, discontinuous in some places and where Rubiaceae, Mimosoideae, Myrtaceae and Lauraceae are the most speciose families (Rodrigues, 1996). Understory is relatively dense with high frequency of small trees and bushes. Herbaceous climbers and lianas are common, particularly at the forest edge. Some epiphytes like Orchidaceae, Bromeliaceae, Araceae and Cactaceae species are relatively frequent close to streams (IPJBRJ, 2002) (Figure 1).

\subsection{Sampling}

Winkler's Extractors (Wke): We marked 25 points along a 1,200 $\mathrm{m}$ transect, and at each point we stretched two perpendicular $25 \mathrm{~m}$ lines; one to the left and the other to the right. At the end of each line we delimited a $1 \mathrm{~m}^{2}$ plot, totalling 50 plots. Sifted samples from each plot were separated and placed into Winkler's extractors for 48 hours. This procedure was adapted from Delabie et al. (2000).

Pitfall traps (Pft): We use 50 pitfalls that were distributed along the previously described transect, between the plots with Winkler's extractors. Pitfalls consisted of $300 \mathrm{~mL}$ plastic glasses with a diameter of $7.0 \mathrm{~cm}$, containing $3 \%$ formalin. Pitfalls were buried in the soil with the upper border parallel to the ground, and remained open for 48 hours.

\subsection{Identification of ants}

Ant genera were identified following Bolton (1994), and subfamilies following Bolton (2003). Whenever
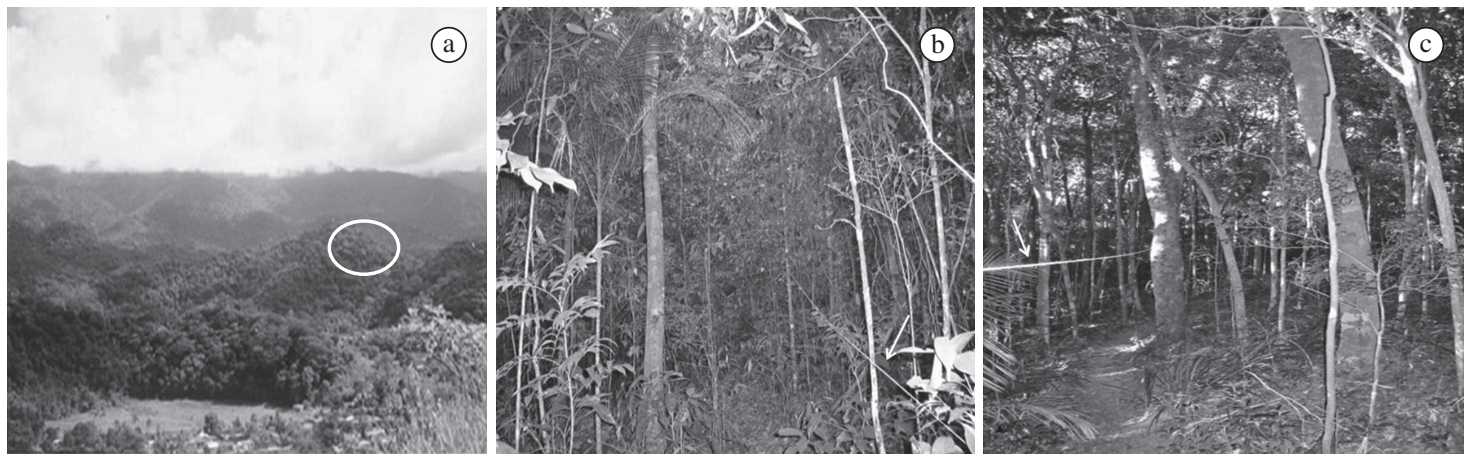

Figure 1. Partial vision of Dense Ombrophylous Forest in "Reserva Biológica do Tinguá". a) The circle shows local study in submontane rainforest; b) Understory relatively dense with high frequency of small trees and bushes; c) Discontinuous canopy in some places is noted. The arrows indicate transects. November/2003. 
possible, identification at species level was carried out with keys from taxonomical reviews or by comparison with identified specimens from the Entomological Collection Ângelo Moreira da Costa Lima (CECL), at the Institute of Biology of the Universidade Federal Rural do Rio de Janeiro, Brazil. Vouchers were deposited in the same collection.

\subsection{Data analysis}

Species accumulation curves were built using the number of samples (Soberón and Llorente, 1993). According to Moreno and Halffter (2000) and Medellín (1993), this method is better for sampling units that grow linearly.

For each technique, the total of species per sample was randomised 1,000 times in the program $\mathrm{EcoSim}^{\circledR}$ (Gotelli and Entsminger, 2009) to estimate confidence intervals (adapted from Lourenço et al., 2010). Accumulation curves were built from observed and randomised data. Logarithmic functions for the randomised curves of each technique were also presented.

\section{Results and Discussion}

In total, we collected ants from ten subfamilies, 37 genera and 105 species (Table 1). Those two methods resulted in a satisfactory sampling of richness; $21.3 \%$ of the genera and $47.6 \%$ of the species were collected exclusively with Winkler's extractors, whereas $6.4 \%$ of the genera and $9.5 \%$ of the species were collected exclusively with pitfalls (Table 2).

Myrmicinae was the most frequent ant subfamily sampled with both techniques, and this result is probably related to the high richness and abundance of this group in the leaf litter fauna of the Neotropics (Silva and Brandão, 1999). Veiga-Ferreira et al. (2005) and Vargas et al. (2007) recorded a high number of species of Myrmicinae in the Atlantic Forest and the Restinga of Rio de Janeiro, respectively. For each of the subfamilies Cerapachyinae and Ecitoninae, only one species was sampled with Winkler's extractors and pitfalls. This result is probably related to habitat conditions that can affect the structure of the ant community (Andersen, 2000; Hölldobler and Wilson, 1990; Nakamura et al., 2003), and consequently the frequency of each species. According to Lassau and Hochuli (2004), the structural complexity of the environment directly affects species richness.

Although pitfall traps tend to capture larger ants (Olson, 1991), such as the specimens of Ectatomminae and Ponerinae recorded in the present study, they can also sample abundance and richness of the leaf litter ant community (Romero and Jaffé, 1989; Wang et al., 2001). Winkler's extractors captured smaller and cryptic leaf litter ants, such as the Myrmicinae, or even ants that are rarely collected with other techniques (Bestelmeyer et at., 2000; Castilho et al., 2007). For the Atlantic Forest,
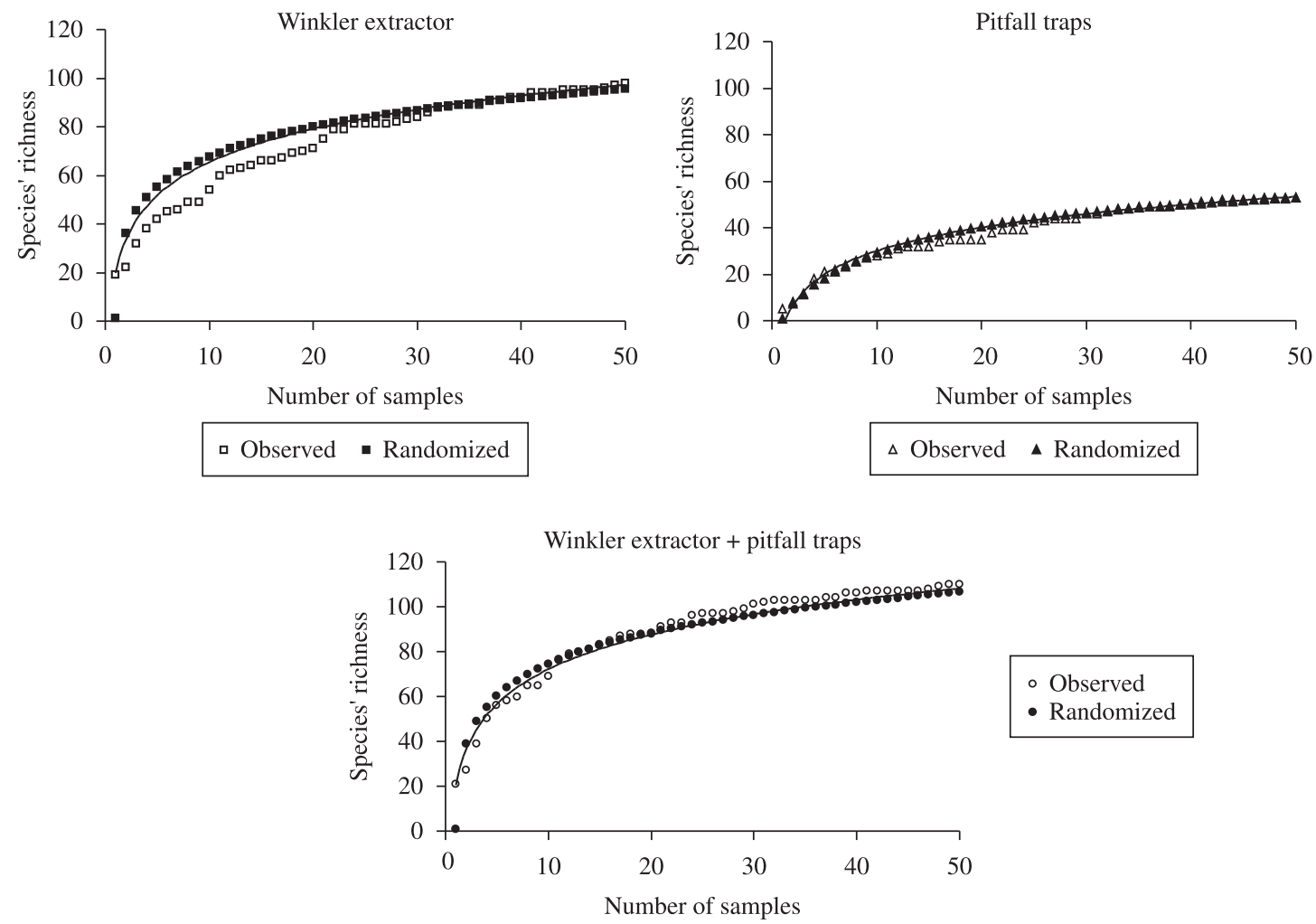

Figure 2. Species accumulation curve observed and using randomised samples. a) Winkler's extractor; b) Pitfall traps; c) Winkler's extractor and Pitfall traps concomitantly. "Rebio Tingua", Brazil, November 2003. 
Table 1. List of species collected by Winkler's extractor and pitfall traps in submontane rainforest in "Reserva Biológica do Tinguá”, Rio de Janeiro state, Brazil. November/2003.

\begin{tabular}{|c|c|c|c|}
\hline Subfamilies & Species/Morphospecies & Winkler's extractor & Pitfall traps \\
\hline \multirow[t]{3}{*}{ Amblyoponinae } & Amblyopone armigera Mayr, 1897 & $\#$ & $\#$ \\
\hline & Amblyopone elongata (Santschi, 1912) & \# & \# \\
\hline & Prionopelta punctulata Mayr, 1866 & $\#$ & - \\
\hline Ceraphachynae & Cerapachys splendens Borgmeier, 1957 & \# & - \\
\hline \multirow[t]{3}{*}{ Dolichoderinae } & Azteca sp.1 & - & \# \\
\hline & Linepithema pulex Wild, 2007 & \# & - \\
\hline & Linepithema sp.1 & \# & \# \\
\hline Ecitoninae & Labidus sp.1 & - & \# \\
\hline \multirow[t]{9}{*}{ Ectatominae } & Ectatomma permagnum Forel, 1908 & \# & - \\
\hline & Ectatomma edentatum Roger, 1863 & \# & - \\
\hline & Ectatomma brunneum F. Smith, 1858 & - & \# \\
\hline & Gnamptogenys cf. horni & $\#$ & - \\
\hline & Gnamptogenys horni Santschi, 1929 & \# & \# \\
\hline & Gnamptogenys rastrata (Mayr, 1866) & \# & \# \\
\hline & Gnamptogenys cf. porcata & \# & - \\
\hline & Gnamptogenys cf. lunaris & \# & - \\
\hline & Gnamptogenys sp.1 & - & \# \\
\hline \multirow[t]{7}{*}{ Formicinae } & Brachymyrmex sp.1 & \# & - \\
\hline & Brachymyrmex sp. 2 & \# & \# \\
\hline & Brachymyrmex sp.3 & \# & \# \\
\hline & Camponotus novogranadensis Mayr, 1870 & \# & - \\
\hline & Camponotus punctulatus Mayr, 1868 & \# & - \\
\hline & Campontous sp.1 & $\#$ & - \\
\hline & Camponotus sp.2 & - & \# \\
\hline Myrmicinae & Acromyrmex aspersus (F. Smith, 1858) & \# & - \\
\hline \multirow[t]{13}{*}{ Attini } & Acromyrmex coronatus (Fabricius, 1804) & \# & - \\
\hline & Acromyrmex niger (F. Smith, 1858) & \# & - \\
\hline & Apterostigma sp.1 & \# & \# \\
\hline & Apterostigma sp. 2 & \# & \# \\
\hline & Cyphomyrmex gr. strigatus sp.1 & \# & \# \\
\hline & Cyphomyrmex gr. strigatus sp. 2 & \# & \# \\
\hline & Cyphomyrmex gr. rimnosus sp. 1 & \# & - \\
\hline & Mycocepurus smithii Forel, 1893 & \# & \# \\
\hline & Mycetarotes carinatus Mayhé-Nunes, 1995 & \# & - \\
\hline & Sericomyrmex sp.1 & \# & \# \\
\hline & Sericomyrmex sp.2 & \# & \# \\
\hline & Sericomyrmex sp.3 & \# & \# \\
\hline & Trachymyrmex sp.1 & \# & \# \\
\hline Myrmicinae & Basiceros bruchi Santschi, 1922 & \# & - \\
\hline \multirow[t]{7}{*}{ Non-Attini } & Basiceros disciger (Mayr, 1887) & \# & - \\
\hline & Basiceros iheringi (Emery, 1887) & \# & - \\
\hline & Basiceros rugiferum (Mayr, 1887) & \# & \# \\
\hline & Carebara urichi (Wheeler, 1922) & $\#$ & \# \\
\hline & Crematogaster nigropilosa Mayr, 1870 & \# & - \\
\hline & Hylomyrma balzani (Emery, 1894) & $\#$ & - \\
\hline & Hylomyrma reitteri (Mayr, 1887) & \# & \# \\
\hline
\end{tabular}

$\#=$ collected by the technique; - = non-collected by the technique . 
Table 1. Continued...

\begin{tabular}{|c|c|c|c|}
\hline Subfamilies & Species/Morphospecies & Winkler's extractor & Pitfall traps \\
\hline & Lachnomyrmex plaumanni Borgmeier, 1957 & $\#$ & - \\
\hline & Megalomyrmex drifti Kempf, 1961 & \# & \# \\
\hline & Megalomyrmex goeldii Forel, 1912 & \# & \# \\
\hline & Megalomyrmex silvestrii Wheeler, 1909 & \# & - \\
\hline & Oxypoecus sp.1 & \# & \# \\
\hline & Oxуроесиs sp.2 & \# & - \\
\hline & Pheidole sp.1 & \# & \# \\
\hline & Pheidole sp.2 & \# & \# \\
\hline & Pheidole sp.3 & \# & \# \\
\hline & Pheidole sp.4 & \# & \# \\
\hline & Pheidole sp.5 & \# & \# \\
\hline & Pheidole sp.6 & \# & \# \\
\hline & Pheidole sp.7 & \# & \# \\
\hline & Pheidole sp.8 & \# & \# \\
\hline & Pheidole sp.9 & \# & - \\
\hline & Pheidole sp.10 & \# & - \\
\hline & Pyramica sp.1 & \# & \# \\
\hline & Pyramica sp.2 & \# & \# \\
\hline & Pyramica sp.3 & $\#$ & - \\
\hline & Pyramica sp.4 & - & \# \\
\hline & Rogeria sp.1 & \# & - \\
\hline & Rogeria sp.2 & \# & - \\
\hline & Rogeria sp.3 & \# & - \\
\hline & Solenopsis sp.1 & \# & \# \\
\hline & Solenopsis sp.2 & \# & \# \\
\hline & Solenopsis sp.3 & \# & - \\
\hline & Solenopsis sp.4 & \# & \# \\
\hline & Solenopsis sp.5 & \# & - \\
\hline & Solenopsis sp.6 & \# & \# \\
\hline & Solenopsis sp.7 & \# & - \\
\hline & Strumigenys elongata Roger, 1863 & \# & - \\
\hline & Wasmannia auropunctata (Roger, 1863) & \# & \# \\
\hline & Wasmannia lutzi Forel 1908 & \# & \# \\
\hline \multirow[t]{14}{*}{ Ponerinae } & Anochetus mayri Emery, 1884 & \# & - \\
\hline & Centromyrmex sp.1 & - & \# \\
\hline & Hypoponera sp.1 & \# & \# \\
\hline & Hypoponera sp.2 & \# & - \\
\hline & Hypoponera sp.3 & \# & - \\
\hline & Hypoponera sp.4 & \# & - \\
\hline & Hypoponera sp.5 & \# & - \\
\hline & Hypoponera sp.6 & \# & - \\
\hline & Leptogenys sp.1 & \# & - \\
\hline & Odontomachus chelifer (Latreille, 1802) & \# & \# \\
\hline & Odontomachus haematodus (Linnaeus, 1758) & - & \# \\
\hline & Odontomachus meinerti Forel, 1905 & $\#$ & - \\
\hline & Odontomachus sp.1 & \# & - \\
\hline & Pachycondyla bucki (Borgmeier, 1928) & \# & - \\
\hline
\end{tabular}

\# = collected by the technique; - = non-collected by the technique. 
Table 1. Continued...

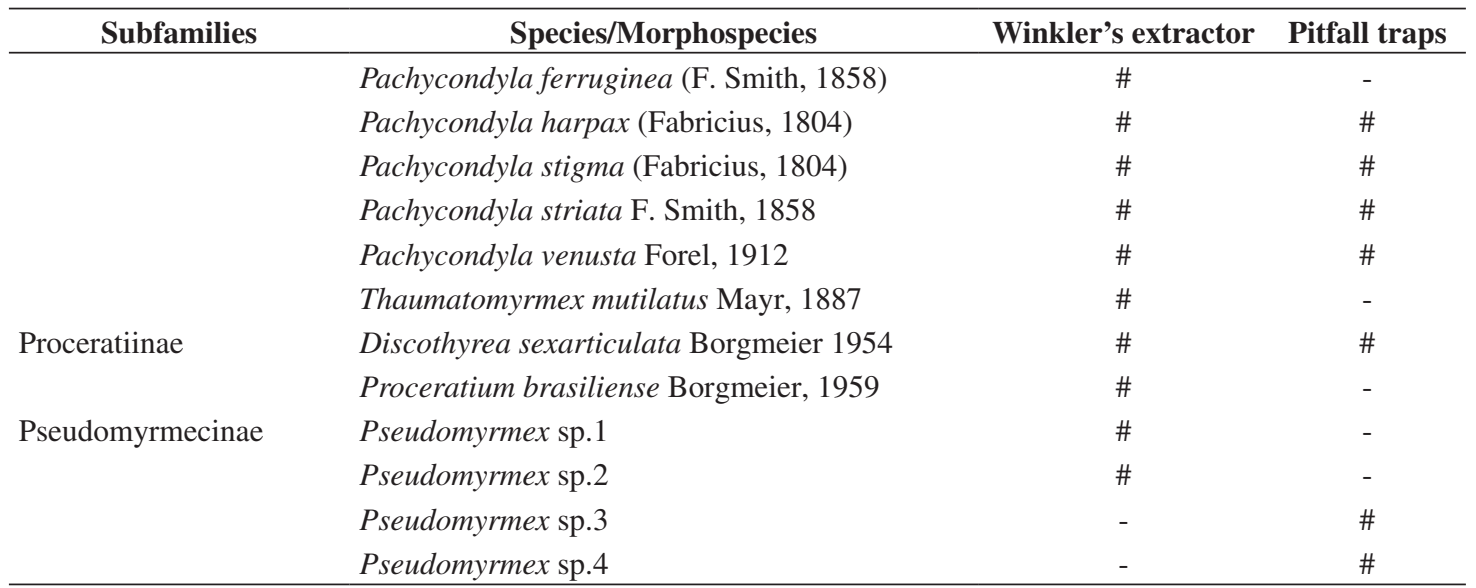

\# = collected by the technique; - = non-collected by the technique.

Table 2. Distribution of genera and species richness of each Formicidae subfamilies sampled by Winkler's extractor (Wke) and pitfall traps (Pft) at "Rebio Tingua", Brazil, November/2003.

\begin{tabular}{|c|c|c|c|c|c|c|c|c|c|c|}
\hline \multirow{3}{*}{$\begin{array}{l}\text { Subfamily } \\
\text { Amblyoponinae }\end{array}$} & \multicolumn{5}{|c|}{ Genera } & \multicolumn{5}{|c|}{ Species } \\
\hline & \multicolumn{2}{|c|}{ Wke } & \multicolumn{2}{|c|}{ Pft } & \multirow{2}{*}{$\begin{array}{c}\begin{array}{c}\text { Common both } \\
\text { techniques }\end{array} \\
1\end{array}$} & \multicolumn{2}{|c|}{ Wke } & \multicolumn{2}{|c|}{ Pft } & \multirow{2}{*}{$\begin{array}{c}\begin{array}{c}\text { Common both } \\
\text { techniques }\end{array} \\
2\end{array}$} \\
\hline & 2 & (1) & 1 & $(-)$ & & 3 & (1) & 2 & $(-)$ & \\
\hline Cerapachyinae & 1 & (1) & - & - & - & 1 & (1) & - & - & - \\
\hline Dolichoderinae & 1 & $(-)$ & 2 & (1) & 1 & 2 & (1) & 2 & (1) & 1 \\
\hline Ecitoninae & - & - & 1 & (1) & - & - & - & 1 & (1) & - \\
\hline Ectatomminae & 2 & $(-)$ & 2 & $(-)$ & 2 & 7 & (5) & 4 & (2) & 2 \\
\hline Formicinae & 2 & $(-)$ & 2 & $(-)$ & 2 & 6 & (4) & 3 & (1) & 2 \\
\hline Myrmicinae & 20 & (4) & 9 & $(-)$ & 14 & 54 & (23) & 32 & (1) & 31 \\
\hline Ponerinae & 6 & (3) & 4 & (1) & 3 & 20 & (12) & 8 & (2) & 6 \\
\hline Proceratiinae & 2 & (1) & 1 & $(-)$ & - & 2 & (1) & 1 & $(-)$ & 1 \\
\hline Pseudomyrmecinae & 1 & $(-)$ & 1 & $(-)$ & 1 & 2 & (2) & 2 & (2) & - \\
\hline Total & 37 & (10) & 23 & (3) & 24 & 97 & (50) & 55 & (10) & 45 \\
\hline
\end{tabular}

Exclusive genera and species for each technique are within parenthesis.

Winkler's extractor had proven to be the most efficient single sampling technique to estimate richness. However, pitfalls also recorded a significant portion of the total richness. Lassau and Hochuli (2004) collected ants using only pitfalls in complex environments, and, although those environments were different from the one studied here, ant richness was higher in environments with more complex structures. Therefore, pitfalls must be used together with other sampling techniques in the field, especially in tropical forests.

On the one hand, our results are consistent with Parr and Chown (2001), who, when comparing sampling techniques, suggested that species collected with Winkler's extractors are more abundant and smaller than the ones collected in pitfalls. On the other hand, Olson (1991) showed that Winkler's extractors and pitfalls together can sample c. $75.0 \%$ of the species richness estimated for the leaf litter ant fauna, a percentage considered reasonable for ecological studies on leaf litter.

Despite differences in efficiency, species accumulation curves for both techniques were similar $\left(y=19.743 \operatorname{Ln}(x)+19.962 ; r^{2}=0.9688 ; p<0.001\right.$ for Wke, $y=14.487 \operatorname{Ln}(x)-3.348 ; r^{2}=0.995 ; p<0.001$ for Pft), as well as the curve obtained with both methods combined $\left(y=22.378 \operatorname{Ln}(x)+20.575 ; r^{2}=0.9739\right.$; $\mathrm{p}<0.001$ for Wke $+\mathrm{Pft}$ ) (Figure 2). To obtain the total of 105 species recorded with both techniques combined, it would be necessary to take 64.07 samples with Wke and 111.84 with Pft. Therefore, we noticed that Winkler's extractors were c. $74.0 \%$ more efficient than pitfalls in the Atlantic Forest, corroborating results from Parr and Chown (2001).

Sampling techniques must be used with a well-structured sampling design in order to advance knowledge on the 
ant fauna of Brazilian biomes, especially in the leaf litter (Castilho et al. (2007) and Veiga-Ferreira et al. (2010) for new records of ant's species), allowing more complete environmental analyses. The influence of ants on edaphic processes, flux of energy and matter in ecosystems (Brown, 1997), predation, and seed dispersal (Folgarait, 1998; Passos and Oliveira, 2002, 2003; Leal, 2003) makes this insect group a good study model for environmental surveys and monitoring (Silva and Brandão, 1999).

Acknowledgements - We are grateful to the team at the Reserva Biológica do Tinguá (Nova Iguaçu office) and to IBAMA for the study license. This study was supported by grants from the Brazilian governmental to GOS (CAPES), to AJMN and CELS (CNPq).

\section{References}

ANDERSEN, AN., 2000. A global ecology of rain forest ants: Functional groups in relation to environmental stress and disturbance. In AGOSTI, D., MAJER, JD., ALONSO, LE. and SCHULTZ, TR. (Eds.). Ants: Standard methods for measuring and monitoring biodiversity. Washington: Smithsonian Institutions Press. p. 25-34

AGOSTI, D. and ALONSO, LE., 2001. The all Protocol: a standard protocol for the collection of ground-dwelling ants. Anet Newsletter, vol. 3, p. 8-11.

AGOSTI, D., MAJER, JD., ALONSO, LE. and SCHULTZ, TR. (Eds.)., 2000. Ants: standand (Hymenoptera: Formicidae) methods for measuring and monitoring biodiversity. Washington: Smithsonian Institutions Press. 280 p.

BESTELMEYER, BT., AGOSTI, D., ALONSO, LE., BRANDÃO, CRF., BROWN JUNIOR, WL., DELABIE, JHC. and SILVESTRE, R., 2000. Field techniques for the study of ground-living ants: An overview, description, and evaluation. In AGOSTI, D., MAJER, JD., ALONSO, LT. and SCHULTZ, TR. (Eds.). Ants: Standard methods for measuring and monitoring biodiversity. Washington: Smithsonian Institutions Press. p.122-144

BOLTON, B., 1994. Identification Guide to the Ant Genera of the World. London: Harvard University Press. 222 p.

-, 2003. Synopsis and classification of Formicidae. Memoirs of the American Entomological Instistitute, vol. 71, p. 1-370.

BRAZ, DM., MOURA, MVLP. and ROSA, MMT., 2004. Chave de identificação para as espécies de Dicotiledôneas arbóreas da Reserva Biológica do Tinguá, RJ, com base em caracteres vegetativos. Acta Botanica Brasilica, vol. 18, no. 2, p. 225-250.

BROWN, KS., 1997. Diversity, disturbance and sustainable use of Neotropical forests: insects as indicators for conservation monitoring. Journal of Insect Conservation, vol. 1, no. 1, p. 1-18. http://dx.doi.org/10.1023/A:1018432508944

CASTILHO, ACC., DELABIE, JHC., MARQUES, MI., ADIS, J. and MENDES, LF., 2007. Registros Novos da Formiga Criptobiótica Creightonidris scambognatha Brown (Hymenoptera: Formicidae). Neotropical Entomology, vol. 36, no. 1, p. 150-152. PMid:17420875. http://dx.doi.org/10.1590/S1519-566X2007000100020

COLWELL, RK. and CODDINGTON, JA., 1994. Estimating terrestrial biodiversity through extrapolation. Philosophical Transactions of the Royal Society of London, Series B, vol. 345, p. 101-118. PMid:7972351. http://dx.doi.org/10.1098/rstb.1994.0091
DELABIE, JHC., AGOSTI, D. and NACIMEJNTO, IC., 2000. Litter ant communities of the Brazilian Atlantic rain forest region. In AGOSTI, D., MAJER, JD., ALONSO, LT. and SCHULTZ, TR. (Eds.). Sampling ground-dwelling ants: case studies from the world's rain forests. Perth, Australia: Curtin University School of Environmental Biology. p. 1-17. (Bulletin, vol. 18).

FOLGARAIT, PJ., 1998. Ant biodiversity and its relationship to ecosystem functioning: a review. Biodiversity and Conservation, vol. 7, p. 1221-1244. http://dx.doi.org/10.1023/A:1008891901953

GASTON, KJ., 1996. Species richness: measure and measurement. In GASTON, KL. (Ed.). Biodiversity: a biology of numbers and difference. Cambridge: Blackwell Science. p. 77-113.

GOTELLI, N.J. and ENTSMINGER, GL., 2009. EcoSim: Null models software for ecology. Version 7. Jericho: Acquired Intelligence Inc. \& Kesey-Bear. Available from: <http://garyentsminger.com/ ecosim.htm>. Access in: 05 jul. 2010.

HÖLLDOBLER, B. and WILSON, EO., 1990. The Ants. Cambrigde: The Belknap Press of Havard University. 733 p.

Instituto Brasileiro do Meio Ambiente e dos Recursos Naturais Renováveis - IBAMA, 1996. Plano de ação emergencial - Reserva Biológica do Tinguá. Brasília: IBAMA, 114 p.

Instituto de Pesquisas Jardim Botânico do Rio de Janeiro, 2002. Projeto Tinguá: Paisagem e flora da reserva biológica do Tinguá: subsídios ao monitoramento da vegetação. Rio de Janeiro: Instituto de Pesquisas Jardim Botânico do Rio de Janeiro, Universidade Federal Rural do Rio de Janeiro. 55 p. Relatório técnico-cientifico.

LASSAU, SA. and HOCHULI, DF., 2004. Effects of habitat complexity on ant assemblages. Ecography, vol. 27, no. 2, p. $157-164$.

LEAL, IR., 2003, Dispersão de Sementes por Formigas. In LEAL, IR., TABARELLI, M. and SILVA, JMC. Ecologia e Conservação da Caatinga. Recife: Ed. Univ. UFPE. p. 593-624.

LONGINO, JT., CODDINGTON, J. and COLWELL, RK., 2002. The ant fauna of a tropical rain forest: estimating species richness three different ways. Ecology, vol. 83, no. 3, p. 689-702. http:// dx.doi.org/10.1890/0012-9658(2002)083[0689:TAFOAT]2.0.CO;2

LOURENÇO, EC., COSTA, LM., SILVA, RM. and ESBÉRARD, CEL., 2010. Bat diversity of Ilha da Marambaia, Southern Rio de Janeiro State, Brazil (Chiroptera, Mammalia). Brazilian Journal of Biology, vol. 70, no. 3, p. 511-519. http://dx.doi.org/10.1590/ S1519-69842010000300007

MEDELLÍN , RA., 1993. Estructura y diversidad de una comunidad de murciélagos en el trópico húmedo mexicano. In MEDELLÍN, RA. and CEBALLOS, TG. (Eds.). Avances en el estudio de los mamíferos de México. México: Asociación Mexicana de Mastozoología. vol. 1, p 333-354.

MORENO, CE. and HALFFTER, G., 2000. Assessing the completeness of bat biodiversity inventories using species accumulation curves. Journal of Applied Ecology, vol. 37, p. 149-158. http://dx.doi.org/10.1046/j.1365-2664.2000.00483.x

NAKAMURA, A., PROCTOR, H. and CATTERALL, CP., 2003. Using soil and litter arthropods to assess the state of rainforest restoration. Ecological Management \& and Restoration, vol. 4, p. 20-28. PMid:17923455. http://dx.doi.org/10.1046/j.14428903.4.s.3.x

OLSON, DM., 1991. A comparison of the efficacy of litter sifting and pitfall traps for sampling leaf litter ants (Hymenoptera: 
Formicidae) in a Tropical wet forest, Costa Rica. Biotropica, vol. 23, no. 2, p. 166-172.

PARR, CL. and CHOWN, SL., 2001. Inventory and bioindicator sampling: testing pitfall and Winkler methods with ants in a South African savanna. Journal of Insect Conservation, vol. 5, p. 27-36. http://dx.doi.org/10.1023/A:1011311418962

PASSOS, L. and OLIVEIRA, PS., 2002. Ants affect the distribution and performance of seedlings of Clusia criuva, a primarily birddispersed rain forest tree. Journal of Ecology, vol. 90, p. 517-528. http://dx.doi.org/10.1046/j.1365-2745.2002.00687.x

PASSOS, L. and OLIVEIRA, PS., 2003. Interactions between ants, fruits and seeds in a restinga forest in south-eastern Brazil. Journal of Tropical Ecology, vol. 19, p. 261-270. http://dx.doi. org/10.1017/S0266467403003298

RODRIGUES, HC. 1996. Composição florística e fitossociológica de um trecho de Mata Atlântica na Reserva Biológica do Tinguá, Nova Iguaçu, Rio de Janeiro. Rio de Janeiro: Museu Nacional, Universidade Federal do Rio de Janeiro. 77 p. Dissertação de Mestrado.

ROMERO, H. and JAFFE, K., 1989. A comparison of methods for sampling ants (Hymenoptera:Formicidae) in savannas. Biotropica, vol. 21, no. 4, p. 348-352. http://dx.doi.org/10.2307/2388285

SILVA, RR. and BRANDÃO, CRF., 1999. Formigas (Hymenoptera: Formicidae como indicadores da qualidade ambiental e da biodiversidade de outros invertebrados terrestres. Biotemas, vol. 12 , no. 2 , p. 55-73.
SOBERÓN, J. and LLORENTE, J., 1993. The use of species accumulation functions for the prediction species richness. Conservation Biology, vol. 7, no. 3, p. 480-488. http://dx.doi. org/10.1046/j.1523-1739.1993.07030480.x

VARGAS, AB., MAYHÉ-NUNES, AJ., QUEIROZ, JM., SOUZA, GO. and FOLLY-RAMOS, E., 2007. Efeitos de Fatores Ambientais sobre a Mirmecofauna em Comunidade de Restinga no Rio de Janeiro, RJ. Neotropical Entomology, vol. 36, no. 1, p. 28-37. PMid:17420859. http://dx.doi.org/10.1590/S1519566X2007000100004

VEIGA-FERREIRA, S., MAYHÉ-NUNES, AJ. and QUEIROZ, JM., 2005. Formigas de serapilheira na Reserva Biológica do Tinguá, Estado do Rio de Janeiro, Brasil (Hymenoptera: Formicidae). Revista Universidade Rural, Série Ciências da Vida, vol. 25 , no. 1 , p. $49-54$.

VEIGA-FERREIRA, S., ORSOLON-SOUZA, G. and MAYHÉNUNES, AJ., 2010. Hymenoptera, Formicidae Latreille, 1809: New records for Atlantic Forest in the state of Rio de Janeiro. Check List, vol. 6, no. 3, p. 442-444.

VELOSO, HP., RANGEL-FILHO, ALR. and LIMA, JCA., 1991. Classificação da Vegetação brasileira adaptada a um sistema universal. Rio de Janeiro: IBGE. $124 \mathrm{p}$.

WANG, C., STRAZANAC, J. and BUTLER, L., 2001. A comparison of Pitfall Traps with Bait Traps for studying leaf litter ant communities. Journal Economic Entomology, vol. 94, no. 3, p. 761-765. PMid:11425034. http://dx.doi.org/10.1603/00220493-94.3.761 